\title{
Methodiek schoolverlatersinformatiesysteem 1998
}

Citation for published version (APA):

Huijgen, T. G., \& Wolbers, M. H. J. (1999). Methodiek schoolverlatersinformatiesysteem 1998.

Researchcentrum voor Onderwijs en Arbeidsmarkt, Faculteit der Economische Wetenschappen. ROA

Working Papers No. 5 https://doi.org/10.26481/umarow.1999005

Document status and date:

Published: 01/01/1999

DOI:

10.26481/umarow.1999005

Document Version:

Publisher's PDF, also known as Version of record

\section{Please check the document version of this publication:}

- A submitted manuscript is the version of the article upon submission and before peer-review. There can be important differences between the submitted version and the official published version of record.

People interested in the research are advised to contact the author for the final version of the publication, or visit the DOI to the publisher's website.

- The final author version and the galley proof are versions of the publication after peer review.

- The final published version features the final layout of the paper including the volume, issue and page numbers.

Link to publication

\footnotetext{
General rights rights.

- You may freely distribute the URL identifying the publication in the public portal. please follow below link for the End User Agreement:

www.umlib.nl/taverne-license

Take down policy

If you believe that this document breaches copyright please contact us at:

repository@maastrichtuniversity.nl

providing details and we will investigate your claim.
}

Copyright and moral rights for the publications made accessible in the public portal are retained by the authors and/or other copyright owners and it is a condition of accessing publications that users recognise and abide by the legal requirements associated with these

- Users may download and print one copy of any publication from the public portal for the purpose of private study or research.

- You may not further distribute the material or use it for any profit-making activity or commercial gain

If the publication is distributed under the terms of Article $25 \mathrm{fa}$ of the Dutch Copyright Act, indicated by the "Taverne" license above, 


\section{Methodiek Schoolverlatersinformatiesysteem 1998}

ROA-W-1999/5

Timo Huijgen en Maarten Wolbers

Researchcentrum voor Onderwijs en Arbeidsmarkt

Faculteit der Economische Wetenschappen en Bedrijfskunde Universiteit Maastricht

Maastricht, november 1999 
ISBN 90-5321-278-7

SEC99145/TH 
Inhoud

Bladzijde

Voorwoord

1 Inleiding 1

2 Schoolverlatersonderzoeken 1

3 Dataverwerking en weging 3

4 Dekkingsgraad en respons $\quad 7$

5 Non-respons 12

6 Besluit 16

$\begin{array}{ll}\text { Literatuur } & 17\end{array}$

Appendix A: Kernvragenlijst $\quad 19$ 



\section{Voorwoord}

Dit werkdocument gaat in op de methodiek die in het uitvoeringsjaar 1998 is gehanteerd binnen het schoolverlatersonderzoek zoals dat door het ROA wordt uitgevoerd. Dit betreft de enquêtes Registratie van Uitstroom en Bestemming van Schoolverlaters (RUBS), HBO-Monitor en WOMonitor. Sinds 1996 is het ROA-schoolverlatersonderzoek in vergaande mate geïntegreerd. Hierdoor is een vergelijkbaar systeem ontstaan, het Schoolverlatersinformatiesysteem (SIS) genoemd, met gegevens over schoolverlaters uit vrijwel het gehele secundair en tertiair onderwijs. In het kader van het onderzoek binnen dit informatiesysteem zijn onder andere het rapport Schoolverlaters tussen onderwijs en arbeidsmarkt 1998 en een bijbehorende bijlage Statistische Bijlage gepubliceerd. Daarnaast is er een specifieke rapportage verschenen over de arbeidsmarktpositie van de afgestudeerden van het HBO. De lerarenopleidingen zullen in een aparte rapportage worden behandeld. Voor de afgestudeerden van het kunstvakonderwijs verschijnt in de loop van 2000 ook een specifiek rapport. Tevens zullen de belangrijkste resultaten van de WO-Monitor in een landelijke rapportage worden gepresenteerd. Naast de hierboven genoemde schoolverlatersonderzoeken zijn in 1998 enkele, in 1997 gestarte, 'pilot'onderzoeken voortgezet. Dit betreft enquêtes onder schoolverlaters van de Beroepsbegeleidende leerweg (BBL) en ex-cursisten van het Voortgezet Algemeen Volwassenen Onderwijs (VAVO). Er is eveneens een éénmalige enquête verricht onder ex-cursisten van de basiseducatie (BE). Hierover zal in aparte rapportages zowel methodologisch als inhoudelijk verslag worden gedaan.

Het Schoolverlatersinformatiesysteem wordt financieel mogelijk gemaakt door de Ministeries van Onderwijs, Cultuur en Wetenschappen, Sociale Zaken en Werkgelegenheid en Landbouw, Natuurbeheer en Visserij, het Expertisecentrum voor Loopbaanvraagstukken LDC, de HBO-Raad, de VSNU en de deelnemende onderwijsinstellingen. Bij de uitvoering van het onderzoek werkt het ROA samen met DESAN Marktonderzoek b.v. te Amsterdam en STOAS Onderzoek te Wageningen. Binnen het ROA is de projectleiding van het Schoolverlatersinformatiesysteem in handen van dr. R.K.W. van der Velden en dr. M.H.J. Wolbers. Dit werkdocument is samengesteld door drs. T.G. Huijgen. Verder hebben aan het Schoolverlatersinformatiesysteem 1998 meegewerkt dr. J.P. Allen, E.J. Potma, P.J.E.G. van der Kolk, drs. G.W.M. Ramaekers, drs. L.M. Smit en E.M.H.P. Soudant (allen werkzaam bij ROA), alsmede M. van Alphen, drs. K.R. Becker, drs. H. van Dongen, drs. ing. K.J. Pagrach, ing. J.J. Rutjes (allen werkzaam bij DESAN Marktonderzoek) en ing. M.C. Gimbrère, dr. A.H. Lokman, drs. M.A.M. van der Meijs, dr. C.H.A. Verhaar (allen werkzaam bij STOAS Onderzoek). 


\section{Inleiding}

Door het ROA worden jaarlijks drie grootschalige schoolverlatersonderzoeken uitgevoerd. In de eerste plaats betreft dit een onderzoek onder de schoolverlaters van het Algemeen Voortgezet Onderwijs (AVO), het Voorbereidend Beroepsonderwijs (VBO) ${ }^{1}$ en de Beroepsopleidende leerweg (BOL) van het secundair beroepsonderwijs aan de hand van de enquête Registratie van Uitstroom en Bestemming van Schoolverlaters (RUBS). In de tweede plaats is dit een onderzoek onder de afgestudeerden van het Hoger Beroepsonderwijs (HBO) via de HBO-Monitor. In de derde plaats wordt onderzoek verricht onder de afgestudeerden van de universiteiten (de WOMonitor). Deze schoolverlatersonderzoeken vormen de basis voor een aantal landelijke publicaties, zoals de recent verschenen rapporten Schoolverlaters tussen onderwijs en arbeidsmarkt 1998 en De arbeidsmarktpositie van afgestudeerden van het hoger beroepsonderwijs; HBOMonitor 1998.

Dit werkdocument vormt een methodologische aanvulling op deze reeds verschenen en nog te verschijnen rapporten. Er zal met name worden ingegaan op de gehanteerde methodiek, de respons en het uitgevoerde non-responsonderzoek. De opzet van de rest van dit werkdocument is als volgt. Allereerst wordt in paragraaf 2 een uiteenzetting gegeven over het doel en de opzet van de schoolverlatersonderzoeken. Vervolgens wordt in paragraaf 3 ingegaan op de dataverwerking en de weging van de gegevens. In paragraaf 4 wordt daarna een overzicht gegeven van de dekkingsgraad en de respons. Paragraaf 5 bevat een verslag van het non-responsonderzoek. In paragraaf 6 wordt dit werkdocument ten slotte kort samengevat.

\section{Schoolverlatersonderzoeken}

Doel

De schoolverlatersenquêtes van het ROA zijn gericht op het monitoren en analyseren van de bestemming van (gediplomeerde) schoolverlaters in het vervolgonderwijs en op de arbeidsmarkt. Daarbij kunnen twee componenten worden onderscheiden: een toepassingscomponent en een onderzoekscomponent. De toepassingscomponent richt zich op de zorg van individuele onderwijsinstellingen voor de onderwijskwaliteit en de afstemming van het onderwijs op de behoeften van de arbeidsmarkt. Daarvoor worden zogenaamde instellingsrapportages opgesteld waarin de onderwijsinstellingen informatie krijgen over hun eigen afgestudeerden, waar relevant afgezet tegen het landelijke beeld. Hiermee kunnen management, studierichtingsleiders en decanaat een indruk krijgen van het externe rendement van hun opleidingen.

De onderzoekscomponent van het schoolverlatersonderzoek, aangeduid als het Schoolverlatersinformatiesysteem (SIS), heeft als doel het analyseren van het doorstroompatroon van schoolverlaters naar vervolgonderwijs en het transitieproces van school naar werk. De resultaten hiervan worden onder meer gepubliceerd via algemeen toegankelijke landelijke rapportages. Hierin ligt het accent op (de ontwikkelingen in) het intredeproces van schoolverlaters, de kansen

1. Inclusief het Individueel Voorbereidend beroepsonderwijs (IVBO). 
op het vinden van werk, de kwaliteit van het werk en het keuzegedrag van schoolverlaters ten aanzien van mogelijke vervolgopleidingen en de kwaliteit van de aansluiting die daarbij wordt ondervonden.

Opzet

Zoals is aangegeven vormt een drietal schoolverlatersonderzoeken (RUBS, HBO-Monitor en WO-Monitor) de basis van het Schoolverlatersinformatiesysteem. Voor al deze schoolverlatersonderzoeken geldt dat onderwijsinstellingen zelf aangeven of zij met (een deel van) hun schoolverlaters of afgestudeerden willen deelnemen. De RUBS-enquête wordt bij de scholen aangeboden onder verantwoordelijkheid van het LDC. De HBO-Monitor wordt bij de hogescholen aangeboden onder auspiciën van de HBO-Raad. De WO-Monitor vindt in VSNUverband plaats. Het ROA draagt zorg voor de uitvoering van de WO-Monitor voor negen universiteiten en heeft daarnaast de landelijke coördinatie. De Rijksuniversiteit Groningen, de Katholieke Universiteit Nijmegen, de Universiteit Twente en de Universiteit Utrecht hebben de enquête zelf uitgevoerd. Ook de gegevens van deze 'lokale' uitvoerders zijn opgenomen in het Schoolverlatersinformatiesysteem. Binnen het agrarisch onderwijs worden de resultaten van de onderzoeken aangeboden door STOAS Onderzoek te Wageningen.

Door bovengenoemde werkwijze is er geen sprake van een aselecte steekproef. Met name bij de RUBS-enquête is de dekkingsgraad niet altijd even hoog (zie paragraaf 4). Mochten er echter 'witte vlekken' in de deelname aan RUBS ontstaan - zowel naar opleidingsrichting of regio - dan wordt hier een aanvullende steekproef getrokken. In 1998 is een aanvullende steekproef getrokken voor de opleidingsrichtingen VBO economie (regio zuid), VBO verkoop (regio zuid), AVO, VBO, IVBO, MBO handel, MBO techniek en MBO administratie (allen regio oost), MBO economie (regio noord).

Sinds het uitvoeringsjaar 1996 wordt het schoolverlatersonderzoek van het ROA uitgevoerd volgens een geïntegreerd model, waarbij één meetmoment en één kernvragenlijst wordt onderscheiden. In de praktijk betekent dit dat in de periode oktober-december 1998 ruim 110.000 schoolverlaters en afgestudeerden van het school-/studiejaar 1996/1997 zijn benaderd met een schriftelijke vragenlijst. Wanneer schoolverlaters na ruim een maand de vragenlijst nog niet hebben teruggestuurd, wordt een rappèl verstuurd.

Hoewel de vragenlijsten in de kern gelijk zijn, is ook in het uitvoeringsjaar 1998 enige variatie aan vragen tussen de verschillende vragenlijsten. Hiermee wordt recht gedaan aan de verschillen die er tussen de diverse onderwijsniveaus of -sectoren bestaan.

Binnen RUBS zijn aparte lijsten gebruikt voor de schoolverlaters van MAVO, van HAVO/VWO, van IVBO, van VBO en van MBO. Bovendien zijn voor het agrarisch onderwijs op zowel (I)VBOals MBO-niveau specifieke vragenlijsten gebruikt. Verder zijn de schoolverlaters van het AVO die de arbeidsmarkt hebben betreden telefonisch ondervraagd over hun arbeidsmarktpositie. Binnen de HBO-Monitor is een aparte vragenlijst opgesteld voor de afgestudeerden van het landbouwonderwijs en het pedagogisch onderwijs. Daarnaast zijn onder de naam KunstenMonitor twee specifieke vragenlijsten opgesteld voor afgestudeerden van respectievelijk HBO 
Beeldende Kunst en Vormgeving en HBO Muziek en Theater. In het kader van de WO-Monitor zijn er, naast de standaard WO-lijst, aparte vragenlijsten opgesteld voor het pedagogisch onderwijs en het agrarisch onderwijs (afgestudeerden van de Landbouw Universiteit Wageningen). Tot slot zijn aan alle respondenten van de opleidingen Verzorging (MBO) en Verpleging (MBO en $\mathrm{HBO}$ ) enkele aanvullende vragen voorgelegd.

Om een hogere respons te bereiken, is onder HBO-afgestudeerden van het kunstonderwijs die de schriftelijke vragenlijst niet hebben teruggestuurd een deel van de vragenlijsten telefonisch afgenomen. Afgestudeerden van het pedagogisch onderwijs, op HBO-niveau, die in eerste instantie niet hebben gereageerd op de schriftelijke enquête zijn eveneens integraal telefonisch benaderd.

De vragenlijsten van het uitvoeringsjaar 1998 bestaan uit een viertal hoofdonderwerpen: algemeen (geslacht, leeftijd e.d.), onderwijsloopbaan, arbeidsmarktintrede en een thematisch gedeelte $^{2}$. Binnen de vragenlijsten voor het AVO en het VBO ligt de nadruk op de doorstroom naar het vervolgonderwijs en de redenen van eventuele uitval. Tevens wordt in deze vragenlijsten uitgebreid stilgestaan bij de rol van studie- en beroepskeuzebegeleiding. Er wordt slechts in beperkte mate aandacht besteed aan de arbeidsmarktintrede van deze groep schoolverlaters. Binnen het AVO zijn zoals gezegd aan de werkenden aanvullend telefonisch vragen over hun arbeidsmarktpositie gesteld. In de overige vragenlijsten ligt de nadruk juist op het transitieproces van school naar werk en wordt minder vergaand gevraagd naar de doorstroom naar vervolgonderwijs. In het thematisch gedeelte is in 1998 aandacht besteed aan de waarde die mensen hechten aan bepaalde aspecten verbonden aan werken (zoals zelfstandigheid, het hebben van een vaste baan en het verwerven van een hoog inkomen).

\section{Dataverwerking en weging}

Nadat de vragenlijsten ingevuld zijn teruggestuurd, start het dataverwerkingsproces. Hierbij wordt de informatie afkomstig van de ingevulde vragenlijsten omgezet tot een bestand dat geschikt is voor het uitvoeren van statistische bewerkingen. Dit proces van dataverwerking bestaat uit een aantal stappen: de codering van enkele vragen met open antwoordcategorieën (waaronder vervolgopleiding, beroep, bedrijfssector), de data-entry, de opschoning van het bestand ter voorkoming van mogelijke fouten en eventuele inconsistenties (datacleaning) en de uitbreiding van het bestand met nieuwe variabelen. Vervolgens wordt het bestand gewogen, zodat op basis van de gegevens landelijk representatieve uitspraken kunnen worden gedaan.

\section{Dataverwerking}

De vragenlijsten bevatten voor het merendeel gesloten antwoordcategorieën, waarbij de respondenten kunnen kiezen uit een aantal voorgelegde mogelijkheden. In een beperkt aantal gevallen dienen de schoolverlaters zelf een numerieke waarde in te vullen, bijvoorbeeld bij de kenmerken leeftijd, inkomen en aantal gewerkte uren. Bij enkele vragen wordt gebruik gemaakt

2. Zie bijlage $A$ voor een overzicht van het kerndeel van de vragenlijst. 
van een volledig open vraagstelling, waarbij de schoolverlaters zelf het antwoord op de vraag moeten omschrijven. Dit is met name het geval bij vragen over:

- $\quad$ soort (vervolg- en voor-)opleiding;

- beroep;

- bedrijfssector;

- (woon- of werk-)gemeente.

Bij deze vragen worden de alfanumerieke antwoorden van de respondenten gecodeerd volgens vooraf opgestelde classificaties. Voor de opleidingsvragen wordt daarbij gebruik gemaakt van een speciaal voor dit doel door het ROA opgestelde opleidingsclassificatie, waarin alle in Nederland voorkomende (reguliere) opleidingen zijn opgenomen ${ }^{3}$. Beroep en bedrijfssector worden gecodeerd volgens de Standaard Beroepen Classificatie 1992 (SBC'92) en de Standaard Bedrijfsindeling 1993 (SBI'93) van het CBS. Overigens zijn beide classificaties, waar relevant, door het toevoegen van een extra digit verder verbijzonderd. Gemeenten worden gecodeerd volgens de gemeentecodes die door het CBS in het meest recente Plaatsnamenregister worden gehanteerd.

$\mathrm{Na}$ automatische data-invoer worden de aldus verkregen ruwe gegevens vervolgens onderworpen aan een uitgebreide kwaliteitscontrole. Doel van deze controle is om eventuele onvolkomenheden, fouten en inconsistenties te achterhalen en zo mogelijk te corrigeren ${ }^{4}$. Het proces van kwaliteitscontrole van de gegevens is in een viffal fasen onderverdeeld:

1. Algemene controle: dit is een uitgebreide controle om te achterhalen of er bij de data-entry problemen zijn opgetreden en of de gegevens ten aanzien van de gevolgde opleiding juist zijn.

2. Controle op variabelen met "anders-categorie": hierin wordt bekeken of er bij de vragen met een antwoordcategorie "anders, namelijk ..." bepaalde overeenkomstige antwoorden kunnen worden onderscheiden zodat vervolgens eventuele nieuwe antwoordcategorieën worden aangemaakt.

3. Controle per blok ${ }^{5}$ : in deze fase wordt gecontroleerd of de antwoorden op de vragen die bij elkaar horen, overeenkomen. Een voorbeeld kan dit verduidelijken. Stel dat het antwoord op de vraag "Volg je deze vervolgopleiding nog steeds?" ontbreekt, terwijl de vraag waarom de schoolverlater gestopt is met de vervolgopleiding wel ingevuld is. In dat geval wordt het ontbrekende antwoord op de eerste vraag vervangen door "nee, voortijdig verlaten".

3. Daarbij is een rechtstreekse koppeling mogelijk met de Standaard Onderwijs Indeling (SOI) van het CBS.

4. Een groot aantal controles is reeds in de data-entry opgenomen. Dit betreft met name controles op maximum- en minimum-waarden en controles op de in de vragenlijsten gehanteerde verwijzingsstructuren.

5. Blokken in de vragenlijsten zijn bijvoorbeeld "Gevolgde opleiding", "Vervolgopleiding", "Belangrijkste bezigheden" en "Kenmerken huidige functie". 
4. Controle over de blokken heen: hierin wordt nagegaan of de antwoorden op de vragen van verschillende blokken met elkaar overeenstemmen. Bijvoorbeeld: wanneer de eerste maanden van de "kalender" met belangrijkste bezigheden per maand niet zijn ingevuld en de eerste wel ingevulde maand de maand van afstuderen of de eerste maand ná het afstuderen is, dan worden de eerste maanden van de kalender gevuld met scholier/student.

5. Afronding cleaning: tot slot van de cleaning worden de cases die niet bruikbaar zijn uit het bestand verwijderd. Dit zijn onder andere de cases die onverwerkbaar zijn doordat vitale informatie ontbreekt en de cases die niet tot de doelgroep behoren (met name schoolverlaters die in een ander jaar de opleiding hebben verlaten).

In principe is het bestand na de cleaning klaar voor gebruik. Om de bruikbaarheid ervan echter te vergemakkelijken wordt een aantal nieuwe variabelen aan het bestand toegevoegd. Veelal zijn dit variabelen die specifiek zijn gedefinieerd en op meerdere basisvariabelen zijn gebaseerd Zo zijn bijvoorbeeld voor de variabele beroepsbevolking de antwoorden op meer dan vijf vragen nodig.

\section{Weging}

De deelname van de scholen aan de schoolverlatersonderzoeken geschiedt zoals gezegd op vrijwillige basis. Hierdoor ontstaat er in de regel een ongelijke spreiding naar opleiding en regio. Ook naar andere kenmerken van de populatie kan er een niet-representatieve verdeling ontstaan. Zo is de respons bij vrouwen in het algemeen hoger dan bij mannen, waardoor vrouwen oververtegenwoordigd zijn in het onderzoeksbestand. Dergelijke omstandigheden leiden ertoe dat het onderzoeksbestand geen landelijke representatie is van de doelgroep. Om toch betrouwbare landelijke gegevens te kunnen presenteren, wordt een weging uitgevoerd op het bestand zoals dat na de dataverwerking is verkregen. Daarbij wordt een zodanige weging uitgevoerd dat de aantallen uiteindelijk corresponderen met de aantallen in de populatie (ophoging). Voor de weging wordt gebruik gemaakt van populatiegegevens die beschikbaar zijn op basis van de Integrale Leerlingtelling (ILT) voor wat betreft het AVO, VBO en BOL, en het Centraal Register Instellingen Hoger Onderwijs (CRIHO) voor wat betreft het HBO. Beide databestanden worden beheerd door het Ministerie van Onderwijs, Cultuur en Wetenschappen.

Ten aanzien van de schoolverlaters van de landbouwopleidingen wordt gebruik gemaakt van overeenkomstige gegevens beschikbaar gesteld door het Ministerie van Landbouw, Natuurbeheer en Visserij. Voor het WO zijn populatiedata gebruikt van het Ministerie van Onderwijs, Cultuur en Wetenschappen. In de ILT 1996/1997 zijn per instelling en per opleiding gegevens beschikbaar over het aantal leerlingen per leerjaar en geslacht ${ }^{6}$. Het CRIHO bevat per instelling en opleiding gegevens over het aantal diploma's, waarbij eveneens een onderverdeling naar geslacht is gemaakt. In principe wordt op het niveau van opleiding $x$ regio $x$ geslacht een weegfactor bepaald die de verhouding aangeeft tussen het aantal in de populatie en het aantal

6. Helaas zijn gegevens over het aantal gediplomeerden vanwege privacy-redenen tegenwoordig niet meer beschikbaar. Om toch rekening te houden met het rendement van het laatste leerjaar is hiervoor gebruikt gemaakt van gegevens van twee jaar geleden. 
in het onderzoeksbestand. Bij de weging van HBO-opleidingen wordt bovendien een onderscheid gemaakt tussen voltijd- en deeltijdopleidingen. Indien de resulterende weegfactor groter is dan 3 maal de gemiddelde weegfactor en bovendien het aantal cases dat wordt gewogen kleiner is dan 50, dan wordt eerst het kenmerk geslacht en indien noodzakelijk ook het kenmerk regio buiten beschouwing gelaten. In dat geval wordt gewogen op het niveau van opleiding $x$ voltijd/deeltijd (alleen HBO) $x$ regio, respectievelijk opleiding $x$ voltijd/deeltijd (alleen HBO). Voor een aantal opleidingen heeft voorafgaand aan de weging een clustering van opleidingen plaatsgevonden. Op dit hogere clusterniveau wordt vervolgens de weging uitgevoerd. Overigens worden in de schoolverlatersonderzoeken geen landelijke gegevens gepresenteerd wanneer deze betrekking hebben op minder dan 15 respondenten in de steekproef. Tabel 3.1 geeft een overzicht van de aantallen schoolverlaters per opleidingssector vóór en ná de weging. Bij het $\mathrm{HBO}$ is daarbij tevens een onderscheid gemaakt naar voltijd en deeltijd.

Tabel 3.1

Aantallen schoolverlaters per opleidingssector in het ongewogen en gewogen bestand, 1998

\begin{tabular}{lrr}
\hline Opleidingssector & $\begin{array}{c}\text { Ongewogen } \\
\text { aantal }\end{array}$ & $\begin{array}{c}\text { Gewogen } \\
\text { aantal }\end{array}$ \\
\hline AVO & 4.996 & 117.900 \\
MAVO & 1.708 & 52.400 \\
HAVO & 1.778 & 37.400 \\
VWO & 1.510 & 28.100 \\
VBO & & \\
IVBO & 2.039 & 49.200 \\
landbouw & 410 & 7.200 \\
techniek & 554 & 3.800 \\
economie & 410 & 17.700 \\
gezondheidszorg & 304 & 9.600 \\
& 361 & 10.900 \\
BOL niveau 1/2 & & \\
oriënteren en schakelen & 1.280 & 22.700 \\
landbouw & 130 & 8.400 \\
techniek & 83 & 500 \\
economie & 215 & 3.400 \\
gezondheidszorg & 637 & 8.200 \\
& 215 & 2.200 \\
BOL niveau 3/4 & & \\
landbouw & 8.470 & 48.200 \\
techniek & 774 & 3.200 \\
economie & 1.899 & 11.300 \\
gezondheidszorg & 2.751 & 17.600 \\
gedrag en maatschappij & 1.548 & 8.100 \\
& 1.498 & 8.000
\end{tabular}


Tabel 3.1 (vervolg)

Aantallen schoolverlaters per opleidingssector in het ongewogen en gewogen bestand, 1998

\begin{tabular}{lrr} 
Opleidingssector & $\begin{array}{c}\text { Ongewogen } \\
\text { aantal }\end{array}$ & $\begin{array}{c}\text { Gewogen } \\
\text { aantal }\end{array}$ \\
\hline HBO voltijd & 15.991 & 43.100 \\
landbouw & 933 & 1.800 \\
onderwijs & 2.238 & 7.100 \\
techniek & 3.495 & 10.400 \\
economie & 4.327 & 11.600 \\
gezondheidszorg & 1.608 & 3.600 \\
gedrag en maatschappij & 2.144 & 5.100 \\
kunst en cultuur & 1.246 & 3.500 \\
& & \\
HBO deeltijd & 2.404 & 9.200 \\
landbouw & 30 & 100 \\
onderwijs & 774 & 3.500 \\
techniek & 156 & 500 \\
economie & 324 & 1.300 \\
gezondheidszorg & 271 & 1.200 \\
gedrag en maatschappij & 678 & 2.200 \\
kunst en cultuur & 171 & 400 \\
WO & & \\
landbouw & 12.587 & 25.900 \\
techniek & 765 & 1.300 \\
economie & 1.863 & 3.400 \\
gezondheidszorg & 2.041 & 4.700 \\
gedrag en maatschappij & 1.149 & 2.600 \\
taal en cultuur & 2.525 & 4.800 \\
recht en openbare orde & 1.801 & 3.900 \\
natuurwetenschappen & 1.596 & 3.600 \\
& 847 & 1.600 \\
& & \\
& & \\
& & \\
& & \\
& & \\
& & \\
& &
\end{tabular}

\section{Dekkingsgraad en respons}

De schoolverlaters die uiteindelijk in het onderzoeksbestand zijn opgenomen, vormen slechts een gedeelte van de gehele onderzoekspopulatie. Enerzijds worden niet álle personen uit de doelgroep benaderd en anderzijds reageert niet iedereen die wél is benaderd. De dekkingsgraad geeft een beeld van de omvang van het gedeelte van de populatie dat benaderd is. Het responspercentage geeft vervolgens aan welk deel van degenen die benaderd zijn daadwerkelijk heeft gereageerd.

\section{Dekkingsgraad}

Tabel 4.1 laat voor 1998 zien hoe groot de dekkingsgraad per onderwijssoort is. Uit de tabel blijkt dat er tussen de verschillende onderwijssoorten een groot verschil in dekkingsgraad bestaat. De dekkingsgraad bij zowel het AVO als het (I)VBO is laag, maar licht gestegen ten opzichte van verleden jaar. Bij het BOL niveau 1/2 is ook sprake van een lage dekkingsgraad. Hierbij dient 
echter vermeld te worden dat alle uitstromers van de opleiding Oriënteren en Schakelen beschouwd worden als gediplomeerde schoolverlaters. Indien men in acht neemt dat deze schoolverlaters officieel niet tot de gediplomeerden behoren en ze dus buiten beschouwing kunnen worden gelaten bij de berekening, dan stijgt de dekkingsgraad voor het BOL niveau 1/2 van $21 \%$ naar $30 \%$. Bij het HBO is sprake van een hoge deelname. Hier wordt een dekkingsgraad van $73 \%$ bereikt, iets lager dan in 1997 . Bij het WO zijn vrijwel alle afgestudeerden van de reguliere instellingen benaderd, hetgeen resulteert in een dekkingsgraad van $89 \%$.

Tabel 4.1

Dekkingsgraad per onderwijssoort, 1998

\begin{tabular}{|c|c|c|}
\hline Onderwijssoort & $\begin{array}{c}\text { Benaderd } \\
\text { aantal }\end{array}$ & $\begin{array}{c}\text { Dekking } \\
\%\end{array}$ \\
\hline AVO & 9.283 & 8 \\
\hline MAVO & 3.297 & 6 \\
\hline HAVO & 3.487 & 9 \\
\hline VWO & 2.499 & 9 \\
\hline VBO & 4.626 & 9 \\
\hline IVBO & 882 & 12 \\
\hline landbouw & 1.069 & 28 \\
\hline techniek & 1.072 & 6 \\
\hline economie & 734 & 8 \\
\hline gezondheidszorg & 760 & 7 \\
\hline$B O L$ niveau $1 / 2$ & 4.833 & 21 \\
\hline oriënteren en schakelen & 546 & 7 \\
\hline landbouw & 317 & 63 \\
\hline techniek & 810 & 24 \\
\hline economie & 2.461 & 30 \\
\hline gezondheidszorg & 699 & 32 \\
\hline$B O L$ niveau $3 / 4$ & 20.513 & 43 \\
\hline landbouw & 1.818 & 57 \\
\hline techniek & 4.653 & 41 \\
\hline economie & 7.585 & 43 \\
\hline gezondheidszorg & 3.212 & 40 \\
\hline gedrag en maatschappij & 3.245 & 41 \\
\hline$H B O$ & 37.996 & 73 \\
\hline landbouw & 1.731 & 91 \\
\hline onderwijs & 5.302 & 50 \\
\hline techniek & 8.559 & 79 \\
\hline economie & 10.087 & 78 \\
\hline gezondheidszorg & 3.612 & 75 \\
\hline gedrag en maatschappij & 5.779 & 79 \\
\hline kunst en cultuur & 2.926 & 75 \\
\hline WO & 23.058 & 89 \\
\hline
\end{tabular}




\section{Respons}

Zoals uit tabel 4.2 blijkt is de respons ${ }^{7}$ het hoogst bij de schoolverlaters van het AVO (60\%). Het VBO en het BOL niveau $3 / 4$ volgen met $51 \%$. Evenals vorig jaar is bij het BOL niveau $1 / 2$ de respons het laagst, namelijk $39 \%$. Voor het HBO en het WO ligt het responspercentage net onder de $50 \%$. De afgelopen jaren was er een dalende tendens te zien in de respons. Deze tendens heeft zich het afgelopen jaar niet verder voortgezet: voor zowel het AVO, het VBO en het BOL (beide niveaus) is er zelfs sprake van een stijging van de respons ten opzichte van het meetjaar 1997. Het HBO is min of meer stabiel gebleven. Wat verder opvalt is dat er binnen iedere onderwijssoort sprake is van een vrij grote spreiding in de responspercentages. Met name in het HBO (15\%) en in het WO $(21 \%)$ zijn de verschillen groot.

Tabel 4.2

Responspercentage per opleidingssector, 1998

Opleidingssector

$\%$

$\begin{array}{ll}\text { AVO } & 60 \\ \text { MAVO } & 58 \\ \text { HAVO } & 58 \\ \text { VWO } & 66 \\ \text { VBO } & 51 \\ \text { IVBO } & 51 \\ \text { landbouw } & 55 \\ \text { techniek } & 44 \\ \text { economie } & 52 \\ \text { gezondheidszorg } & 53 \\ \text { BOL niveau 1/2 } & \\ \text { oriënteren en schakelen } & 39 \\ \text { landbouw } & 56 \\ \text { techniek } & 35 \\ \text { economie } & 35 \\ \text { gezondheidszorg } & 39 \\ \text { BOL niveau 3/4 } & 42 \\ \text { landbouw } & \\ \text { techniek } & 51 \\ \text { economie } & 53 \\ \text { gezondheidszorg } & 50 \\ \text { gedrag en maatschappij } & 48 \\ \text { HBO } & 56 \\ \text { landbouw } & 54 \\ \text { onderwijs } & \\ \text { techniek } & 49 \\ \text { economie } & 57 \\ \text { gezondheidszorg } & 58 \\ \text { kunst en cultuur } & 43 \\ \end{array}$

7. Voor de berekeningswijze van de respons, zie Willems en Van der Linden (1998). 
Tabel 4.2 (vervolg)

Responspercentage per opleidingssector, 1998

Opleidingssector

$\%$

$W O^{8} \quad 48$

landbouw $\quad 62$

onderwijs $\quad 51$

techniek $\quad 54$

economie 46

gezondheidszorg $\quad 53$

gedrag en maatschappij $\quad 49$

taal en cultuur $\quad 43$

recht en openbare orde $\quad 41$

natuurwetenschappen 48

Door middel van een responsanalyse wordt getracht een beter inzicht te krijgen in de factoren die van invloed zijn op de respons. Aangezien er (per definitie) vrij weinig gegevens bekend zijn over de schoolverlaters die niet gerespondeerd hebben, is de responsanalyse noodzakelijkerwijs beperkt. Er is informatie aanwezig over drie factoren die mogelijk invloed hebben op de respons. Ten eerste is de wijze van verzending van de vragenlijsten bekend. De vragenlijsten kunnen enerzijds centraal door DESAN aan de schoolverlaters worden toegestuurd, anderzijds kunnen de onderwijsinstellingen de vragenlijsten zelf verzenden. Dit laatste noemen we decentrale verzending. Ten tweede is de regioverdeling in de steekproef bekend.

Wellicht geldt dat het responspercentage in de ene regio hoger ligt dan in de andere. Wanneer een bepaalde regio in de loop der jaren een steeds belangrijkere rol is gaan vervullen in de steekproef en als de respons tussen regio's inderdaad verschilt, dan kan dit een verklaring zijn voor veranderingen in de totale respons. Een soortgelijke situatie kan natuurlijk ook gelden voor het opleidingsniveau dat schoolverlaters hebben voltooid. Met behulp van logistische regressieanalyse is nagegaan wat de invloed is van deze drie factoren op de respons. De resultaten van deze analyse staan weergegeven in tabel 4.3.

De analyse toont dat, gecorrigeerd voor regio en wijze van verzending, schoolverlaters van het AVO het vaakst responderen. De respons onder de schoolverlaters van BOL niveau $1 / 2$ is relatief gezien het laagst. Beide bevindingen bevestigen het beeld dat al in tabel 4.2 is aangetroffen. Verder blijkt dat de respons geografisch ongelijkmatig verdeeld is. Evenals de afgelopen jaren is met name de respons in het westen relatief laag. Daarnaast blijkt dat decentraal verzenden geen significant afwijkende respons oplevert dan centrale verzending van vragenlijsten. Uit bovenstaande tabel blijkt verder dat afgestudeerden van het WO beter responderen dan $\mathrm{HBO}$-afgestudeerden, ondanks het feit dat het responspercentage voor het WO $48 \%$ en voor HBO $49 \%$ bedraagt (zie tabel 4.2 ). Wanneer rekening wordt gehouden met de lagere respons in het westen van het land en gezien het feit dat in deze regio relatief veel universiteiten gevestigd zijn, komt de respons onder WO-afgestudeerden hoger te liggen dan

8. De gepresenteerde responspercentages hebben betrekking op 9 van de 13 universiteiten. 
onder afgestudeerde HBO'ers.

Tabel 4.3

De invloed van het opleidingsniveau, de regio en de wijze van verzending op de respons: logit effecten

Onafhankelijke factoren Parameter Standaardfout

Constante

Onderwijssoort:

AVO

VBO

BOL $1 / 2$

BOL 3/4

$\mathrm{HBO}$

WO

Regio:

noord

oost

west

zuid

Decentrale verzending

$N=85.138$
$0,17^{* *}$
0,02

\begin{tabular}{lr}
$0,39^{* *}$ & 0,03 \\
0,02 & 0,04 \\
$0,48^{* *}$ & 0,04 \\
$-0,01$ & 0,02 \\
$-0,16^{* *}$ & 0,02 \\
\multicolumn{2}{r}{ referentiecategorie }
\end{tabular}
$0,15^{\star *} \quad 0,03$
$0,10^{* *} \quad 0,02$
$0,25^{* *} \quad 0,02$
referentiecategorie

$\begin{array}{ll}0,003 & 0,02\end{array}$

** significant op 1\%-niveau

Tabel 4.4

Resultaat dataverzameling in aantallen per onderwijssoort

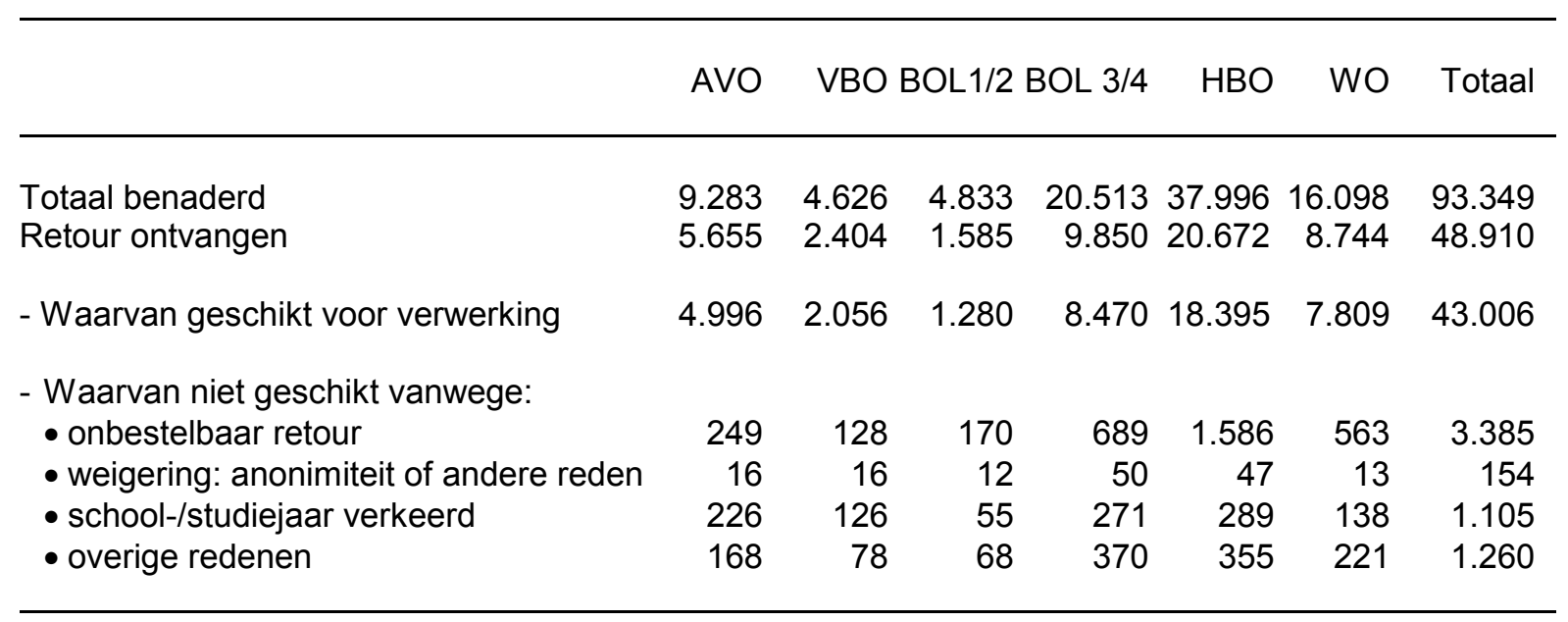

Tabel 4.4 geeft tot slot een overzicht van de in 1998 uitgezette en teruggestuurde vragenlijsten. Dit overzicht geeft bovendien de belangrijkste redenen weer waarom sommige teruggestuurde vragenlijsten niet geschikt zijn voor verwerking. De belangrijkste reden hiervoor is het ontbreken van een juist adres. Voor $3,6 \%$ van de aangeschrevenen is dit het geval. Onder overige redenen vallen onder andere mensen die geen opleiding hebben verlaten maar wel als dusdanig door de onderwijsinstelling waren opgegeven en afgestudeerden die onbereikbaar waren vanwege 
bijvoorbeeld een verblijf in het buitenland of ziekte. De in de tabel gepresenteerde cijfers voor het WO hebben overigens alleen betrekking op die universiteiten waar het ROA de uitvoering van de WO-Monitor voor heeft verzorgd.

\section{Non-respons}

Zoals in paragraaf 4 reeds is vermeld varieert het responspercentage tussen de $39 \%$ (BOL niveau 1/2) en 60\% (AVO). De resultaten zoals die beschreven staan in de landelijke en instellingsrapportages hebben betrekking op deze responsgroep. Om te achterhalen of de onderzoeksresultaten die gebaseerd zijn op de gegevens van deze responsgroep geen vertekening van de werkelijkheid vormen, is het van belang na te gaan of er sprake is van een selectieve (non-)respons. Het mag niet zo zijn dat de groep respondenten en de groep nonrespondenten op kenmerken van elkaar verschillen. Als bijvoorbeeld de schoolverlaters die werkloos zijn grotendeels weigeren aan de enquête deel te nemen ontstaat er wat betreft het kenmerk werkloosheid een verschil tussen de non-responsgroep en de responsgroep. Dit zal vervolgens leiden tot een onderschatting van het werkelijke werkloosheidspercentage, indien dit wordt berekend op basis van de gegevens van de responsgroep.

Eventuele selectiviteit van de (non-)respons kan worden nagegaan door op enkele belangrijke kenmerken de responsgroep met de non-responsgroep te vergelijken. Dit is op twee manieren mogelijk:

(1) door kenmerken van de responsgroep te vergelijken met kenmerken van de doelgroeppopulatie die reeds op basis van andere bronnen bekend zijn, of

(2) door een aanvullend onderzoek te houden onder de non-responsgroep, waarbij over enkele kernvariabelen informatie wordt ingewonnen. Ten behoeve van het schoolverlatersonderzoek is vooraf nauwelijks enige informatie over de populatie bekend behalve over de gevolgde opleiding, het geslacht van de schoolverlaters en de regio van de opleiding. Deze populatiegegevens worden reeds gebruikt om het onderzoekbestand te wegen waardoor op deze punten een landelijk representatief beeld ontstaat zodat voor het nagaan van de mate van selectiviteit van de (non-)respons derhalve een nonresponsonderzoek noodzakelijk is.

De vraag is vervolgens over welke kenmerken van de non-responsgroep informatie verzameld dient te worden. Het antwoord wordt bepaald door het belang dat binnen het schoolverlatersonderzoek aan verschillende kenmerken wordt gehecht en de mate waarin verwacht mag worden dat de respons op deze punten selectief is. De bestemming oftewel de maatschappelijke positie van schoolverlaters na het verlaten van de opleiding kan beschouwd worden als één van de belangrijkste kernpunten in de schoolverlatersenquêtes. Bovendien zou juist op dit punt selectiviteit in de (non-)respons kunnen ontstaan. Evenals in voorgaande jaren is het nonresponsonderzoek voor het uitvoeringsjaar 1998 daarom vooral toegespitst op de bestemming van schoolverlaters.

Een ander belangrijk aspect binnen het schoolverlatersonderzoek omvat het onderzoek onder degenen die betaald werk verrichten. Daarom wordt in het non-responsonderzoek ook getoetst 
op eventuele selectiviteit in het antwoord op de vraag "Heb je op dit moment (ook) betaald werk? (inclusief een betaalde bijbaan en/of een leer-arbeidsplaats)".

\section{Non-responsonderzoek}

Het non-responsonderzoek voor 1998 heeft evenals in afgelopen jaren plaatsgevonden aan de hand van een korte telefonische enquête. De steekproef is gestratificeerd naar onderwijssoort. Binnen een onderwijssoort worden over de verschillende opleidingssectoren aselect schoolverlaters getrokken die in eerste instantie de schriftelijke vragenlijst niet hebben geretourneerd. Dit heeft geleid tot 1.331 respondenten in het non-responsonderzoek. De opleidingssectoren $\mathrm{HBO}$ kunst en cultuur en $\mathrm{HBO}$ pedagogisch onderwijs vormen een uitzondering op deze steekproeftrekking: hier zijn de non-respondenten, zoals eerder is aangegeven, integraal telefonisch benaderd.

Voor het uitvoeren van het telefonisch onderzoek onder de non-respondenten is naast de lijsten die voor het kunst- en het pedagogisch onderwijs zijn gehanteerd gebruik gemaakt van een tweetal verschillende vragenlijsten: één voor non-respondenten van AVO/(I)VBO/BOL/BBL en één voor non-respondenten van het $\mathrm{HBO}$ en het WO. Aan de hand van die lijsten is informatie verzameld over de gevolgde opleiding van de non-respondent, over de belangrijkste bezigheid op het moment van enquêteren en (indien van toepassing) over de huidige baan. Aan alle nonrespondenten is tevens gevraagd naar de reden waarom men in eerste instantie niet heeft deelgenomen aan het onderzoek.

Tabel 5.1

Redenen van schoolverlaters om de schriftelijke vragenlijst niet in te vullen en terug te sturen in percentages per onderwijssoort

$\begin{array}{cccccccc}\text { AVO } & \text { VBO } & \text { BOL } 1 / 2 & \text { BOL 3/4 } & \text { HBO } & \text { WO } & \text { Totaal } \\ \% & \% & \% & \% & \% & \% & \%\end{array}$

Geen echte reden

Vragenlijst nooit ontvangen

Vragenlijst kwijtgeraakt

Vergeten

Geen interesse

Invullen kost teveel tijd/moeite

Bedenkingen bij anonimiteit

en/of privacy

Vragenlijst was niet op mij van

toepassing

lets anders

$\begin{array}{rrr}9 & 8 & 11 \\ 8 & 12 & 15 \\ 4 & 5 & \\ 34 & 24 & 22 \\ 9 & 7 & 10 \\ 21 & 33 & 23\end{array}$

$\begin{array}{rr}11 & 12 \\ 15 & \\ 2 & \\ 22 & 17 \\ 10 & 10 \\ 23 & 36\end{array}$

127

$8 \quad 10$

44

$17 \quad 18$

$10 \quad 6$

$36 \quad 33$

$7 \quad 6$

$6 \quad 8$

$4 \quad 10$

34

$21 \quad 21$

$\begin{array}{rrr}6 & 7 & 8 \\ 33 & 37 & 32\end{array}$

32

$3 \quad 0 \quad 2$

10

3
2
12

0

4

$2 \quad 2$

$\begin{array}{rrrr}1 & 2 & 2 & 2\end{array}$

$\begin{array}{llll}12 & 15 & 20 & 15\end{array}$

Tabel 5.1 laat per onderwijssoort zien wat de redenen van weigering door de non-respondenten zijn geweest. Hierbij gaat het dus om de non-respondenten die in eerste instantie niet hebben deelgenomen aan het onderzoek, maar wel aan de telefonische enquête. De belangrijkste reden waarom schoolverlaters de vragenlijst niet hebben ingevuld en teruggestuurd is dat het invullen 
ervan teveel tijd of moeite kost. Een tweede reden die vaak wordt genoemd is dat men het gewoon vergeten is om de vragenlijst in te vullen en/of op te sturen. Dit is met name bij het AVO het geval. Overigens moet worden bedacht dat er bij het telefonisch benaderen van de non-respondenten wederom non-respons optreedt. De belangrijkste reden voor deze tweede non-respons is dat de schoolverlaters zijn verhuisd of dat het telefoonnummer verkeerd is.

\section{Toets op selectiviteit}

Vervolgens kan worden nagegaan of de responsgroep en de groep die aanvankelijk niet op de schriftelijke enquête heeft gereageerd van elkaar verschillen voor wat betreft de kernvariabelen bestemming en betaald werk. De significantie van dit verschil wordt bepaald aan de hand van de toets van Fisher (zie bijvoorbeeld Van der Genugten, 1986: blz. 298-304). Voordat deze Fishertoets kan worden toegepast, is het echter noodzakelijk om enkele aanpassingen in de databestanden van zowel de non-responsgroep als de responsgroep door te voeren. Allereerst zijn de afgestudeerden van het kunstonderwijs en het hoger pedagogisch onderwijs die telefonisch gereageerd hebben, overgeheveld van de responsgroep naar de non-responsgroep.

Voor onderzoeksdoeleinden behoren ze weliswaar tot de normale respons, maar gezien het feit dat ze de schriftelijke vragenlijst niet hebben geretourneerd, worden ze in het non-respons onderzoek beschouwd als non-respons.

Verder is de verdeling naar opleidingssector verschillend tussen het responsbestand en het nonresponsbestand. Om hiervoor te corrigeren - en dus beide bestanden op dit punt vergelijkbaar te maken - is het responsbestand zodanig (opnieuw) gewogen dat de verdeling over de opleidingssectoren overeenkomt met die van het non-responsbestand ${ }^{9}$. Tabel 5.2 laat per onderwijssoort voor elke bestemmingscategorie het resultaat van de toets van Fisher zien. Voor de volledigheid is aangegeven hoe de bestemming van de non-responsgroep en de responsgroep er in aantallen en percentages uit ziet. De aantallen voor de responsgroep zijn daarbij, zoals gezegd, zodanig aangepast dat de verdeling van de schoolverlaters over de opleidingssectoren binnen de desbetreffende onderwijssoort gelijk is aan de verdeling binnen deze onderwijssoort in het non-responsbestand ${ }^{10}$.

De aantallen in de twee kolommen vormen de basis voor het berekenen van de z-score. Wat opvalt in tabel 5.2 is dat met name op HBO- en WO-niveau er veel significante verschillen zijn tussen de non-respons en de responsgroep. Dit valt gedeeltelijk te verklaren door de grote aantallen respondenten bij beide onderwijssoorten. In de HBO responsgroep hebben minder mensen betaald werk dan in de non-responsgroep, op WO-niveau is dit precies andersom. Verder is er zowel binnen het HBO als het WO in de responsgroep een kleinere 'anders' categorie. Daarnaast geven duidelijk minder AVO-schoolverlaters uit de responsgroep aan doorge-

9. In principe zou het ook mogelijk zijn geweest om het non-responsbestand te herwegen naar het (al dan niet gewogen) responsbestand. Aangezien het non-responsbestand sterk scheef verdeeld is over de opleidingssectoren, zou dit leiden tot zeer hoge en dus onbetrouwbare weegfactoren.

10. Uiteraard zou men de verdelingen nog meer op elkaar kunnen afstemmen door bijvoorbeeld ook rekening te houden met het kenmerk geslacht. Dit is echter niet gedaan, omdat de aantallen in het non-responsbestand daarvoor te klein zijn. 
stroomd te zijn naar het BBL (leerlingwezen) terwijl men in de responsgroep meer is doorgestroomd naar een reguliere studie.

Tabel 5.2

Toets van Fisher op selectiviteit naar bestemming tussen respondenten en non-respondenten per onderwijssoort

\begin{tabular}{|c|c|c|c|c|c|}
\hline \multirow[t]{2}{*}{ Bestemming } & \multicolumn{2}{|c|}{ Non-respons ${ }^{a}$} & \multicolumn{2}{|c|}{ Respons $^{\mathrm{b}, \mathrm{c}}$} & \multirow[t]{2}{*}{ Z-score } \\
\hline & aantal & $\%$ & aantal & $\%$ & \\
\hline \multicolumn{6}{|l|}{ AVO } \\
\hline \|w/in service & 12 & 12 & 147 & 3 & $5,05^{\star *}$ \\
\hline betaald werk & 11 & 11 & 347 & 7 & 1,48 \\
\hline studie & 77 & 75 & 4.360 & 88 & $3,70^{* *}$ \\
\hline werkloos & 1 & 1 & 25 & 1 & 0,67 \\
\hline anders & 1 & 1 & 91 & 2 & 0,64 \\
\hline \multicolumn{6}{|l|}{ VBO } \\
\hline Ilw/inservice & 21 & 24 & 353 & 18 & 1,60 \\
\hline betaald werk & 24 & 24 & 465 & 23 & 0,16 \\
\hline studie & 52 & 51 & 1.121 & 56 & 0,81 \\
\hline werkloos & 0 & 0 & 27 & 1 & 1,17 \\
\hline anders & 1 & 1 & 50 & 2 & 0,95 \\
\hline \multicolumn{6}{|l|}{ BOL niveau $1 / 2$} \\
\hline \|w/inservice & 12 & 11 & 117 & 9 & 0,58 \\
\hline betaald werk & 67 & 61 & 710 & 56 & 0,98 \\
\hline studie & 22 & 20 & 367 & 29 & $2,01^{*}$ \\
\hline werkloos & 7 & 6 & 35 & 3 & $2,10^{*}$ \\
\hline anders & 2 & 2 & 37 & 3 & 0,70 \\
\hline \multicolumn{6}{|l|}{ BOL niveau 3/4 } \\
\hline Ilw/inservice & 9 & 4 & 210 & 2 & 1,67 \\
\hline betaald werk & 121 & 58 & 5.229 & 62 & 1,07 \\
\hline studie & 68 & 33 & 2.739 & 33 & 0,09 \\
\hline werkloos & 5 & 2 & 100 & 1 & 1,59 \\
\hline anders & 4 & 2 & 140 & 2 & 0,30 \\
\hline \multicolumn{6}{|l|}{$H B O$} \\
\hline betaald werk & 1.366 & 89 & 14.431 & 86 & $3,33^{* *}$ \\
\hline studie & 68 & 4 & 1.583 & 9 & $6,54^{* *}$ \\
\hline werkloos & 38 & 2 & 408 & 2 & 0,11 \\
\hline anders & 67 & 4 & 421 & 2 & $4,33^{* *}$ \\
\hline \multicolumn{6}{|l|}{ wo } \\
\hline betaald werk & 270 & 92 & 12.050 & 94 & $-1,37$ \\
\hline studie & 5 & 2 & 278 & 2 & 0,33 \\
\hline werkloos & 5 & 2 & 344 & 3 & 1,29 \\
\hline anders & 15 & 5 & 162 & 1 & $4,78^{* *}$ \\
\hline
\end{tabular}

a. Inclusief telefonische respons (kunst- en pedagogisch onderwijs).

b. Exclusief telefonische respons (kunst- en pedagogisch onderwijs).

c. Gewogen naar de verdeling over de opleidingssectoren in het non-responsbestand. De hier gepresenteerde aantallen wijken derhalve af van de in de (landelijke) rapportages genoemde aantallen.

* Significant op 5\%-niveau

** Significant op 1\%-niveau 
Tabel 5.3

Toets van Fisher op selectiviteit in het aandeel betaald werkende respondenten en het aandeel betaald werkende non-respondenten per onderwijssoort

\begin{tabular}{|c|c|c|c|c|c|}
\hline Betaald werk & \multicolumn{2}{|c|}{ Non-respons ${ }^{a}$} & \multicolumn{2}{|c|}{ Respons $^{b, c}$} & Z-score \\
\hline \multicolumn{6}{|l|}{ VBO } \\
\hline ja & 65 & 64 & 1.160 & 57 & 1,48 \\
\hline nee & 36 & 36 & 879 & 43 & \\
\hline \multicolumn{6}{|c|}{ BOL niveau $1 / 2$} \\
\hline ja & 89 & 81 & 914 & 71 & $2,13^{*}$ \\
\hline nee & 21 & 19 & 366 & 29 & \\
\hline \multicolumn{6}{|c|}{ BOL niveau 3/4 } \\
\hline ja & 176 & 85 & 6.392 & 75 & $3,17^{* *}$ \\
\hline nee & 31 & 15 & 2.078 & 25 & \\
\hline \multicolumn{6}{|l|}{$H B O$} \\
\hline ja & 1.446 & 91 & 15.411 & 90 & 1,74 \\
\hline nee & 144 & 9 & 1.797 & 10 & \\
\hline \multicolumn{6}{|l|}{ WO } \\
\hline ja & 294 & 95 & 12.162 & 93 & 0,97 \\
\hline nee & 16 & 5 & 850 & 7 & \\
\hline
\end{tabular}

a. Inclusief telefonische respons (kunst- en pedagogisch onderwijs).

b. Exclusief telefonische respons (kunst- en pedagogisch onderwijs).

c. Gewogen naar de verdeling over de opleidingssectoren in het non-responsbestand. De hier gepresenteerde aantallen wijken derhalve af van de in de (landelijke) rapportages genoemde aantallen.

* Significant op 5\%-niveau

** Significant op $1 \%$-niveau

Of er sprake is van selectiviteit tussen de respons en de non-responsgroep in het antwoord op de vraag "Heb je op dit moment (ook) betaald werk? (inclusief een betaalde bijbaan en/of een leer-arbeidsplaats)" staat weergegeven in tabel 5.3. De term betaald werk in tabel 5.2 is overigens niet dezelfde als het aandeel betaald werkenden waar in tabel 5.3 naar gekeken wordt. Tabel 5.2 heeft betrekking op de bezigheid die respondenten als hun belangrijkste bezigheid ervaren, terwijl er in tabel 5.3 wordt gekeken of iemand betaald werk heeft of niet, ongeacht of men dit de belangrijkste bezigheid vindt. Uit tabel 5.3 wordt duidelijk dat de responsgroep bij alle opleidingsniveaus over een geringer aantal respondenten met betaald werk beschikt. Voor het BOL (beide niveaus) is dit zelfs significant.

\section{Besluit}

In dit werkdocument wordt de methodiek beschreven van het Schoolverlaters informatiesysteem (SIS) dat door het ROA in 1998 is uitgevoerd. Naast een overzicht van de opzet van dit onderzoek, de gehanteerde classificaties en de uitgevoerde controles en toegepaste correcties op het 
databestand, is vooral ingegaan op de dekkingsgraad, de respons en op het non-respons onderzoek.

Uit het gepresenteerde overzicht van de dekkingsgraad blijkt dat het schoolverlatersonderzoek over het algemeen zeer grootschalig van opzet is. In het AVO is echter sprake van een lage dekkingsgraad (6-9\%). Ook in het VBO en op BOL niveau 1/2 is er sprake van een relatief lage dekkingsgraad. Hierbij dient echter vermeld te worden dan er binnen deze onderwijssoorten aanzienlijke verschillen tussen de sectoren zijn (met name de sector landbouw scoort aanzienlijk hoger). Het BOL niveau $3 / 4$ heeft een dekkingsgraad van $43 \%$; het $\mathrm{HBO}$ scoort hoog met $73 \%$. Aangezien alle reguliere universiteiten participeren in de WO-Monitor 1998 en zodoende vrijwel alle afgestudeerden benaderd worden is hier sprake van een dekkingsgraad van $89 \%$.

De dalende tendens in de responspercentages van de afgelopen jaren heeft zich dit jaar niet verder doorgezet. Het AVO scoort met $60 \%$ het best. Evenals voorgaande jaren is de respons binnen het $\mathrm{BOL}$ niveau $1 / 2$ het laagst (39\%). Bij alle overige onderwijssoorten ligt dit percentage rond de $50 \%$. Als naar regio wordt gekeken blijkt dat schoolverlaters uit de regio west het slechtst responderen. Een belangrijke vraag is of de (non-)respons selectief is. Dit blijkt nauwelijks het geval te zijn, alhoewel werkende schoolverlaters van de BOL (alle niveaus) minder vaak responderen dan niet werkende schoolverlaters van deze onderwijssoort. De algemene conclusie is echter dat op basis van het uitgevoerde onderzoek een goed en betrouwbaar beeld van de bestemming en arbeidsmarktpositie van schoolverlaters wordt verkregen.

Zoals al is opgemerkt, was er in het verleden sprake van een dalende tendens in de responscijfers. Om deze tendens te doorbreken is er bij aanvang van de meting van 1998 een aantal maatregelen genomen. Zo zijn enkele vragenlijsten ingekort en is er een prijs onder de respondenten verloot. Alhoewel het in het algemeen moeilijk is om responsverhogende maatregelen te nemen (en te meten) lijkt het er gezien de iets hogere responscijfers van meetjaar 1998 op dat deze maatregelen toch enig effect hebben gehad.

\section{Literatuur}

Allen, J.P., G.W.M. Ramaekers (1999), De arbeidsmarktpositie van afgestudeerden van het hoger beroepsonderwijs. HBO-Monitor 1998, Voorlichtingsdienst HBO-Raad, Den Haag.

Genugten, B.B. van der (1986), Inleiding tot de waarschijnlijkheidsrekening en mathematische Statistiek deel 1, Stenfert Kroese, Leiden-Antwerpen.

ROA (1999), Schoolverlaters tussen onderwijs en arbeidsmarkt 1998, ROA-R-1999/5, Maastricht (inclusief statistische bijlage).

Willems, E.J.T.A. en A.S.R. van der Linden (1998), Methodiek schoolverlatersinformatiesysteem 1996, ROA-W-1998/1. 


\section{Appendix A: Kernvragenlijst}

Tabel A.1

Overzicht kernvragen Schoolverlatersinformatiesysteem

Variabele

Opmerking

\section{Algemeen}

Geslacht

Leeftijd

Allochtoon

Toestemming doorgeven gegevens aan school

\section{Onderwijsloopbaan}

Gevolgde opleiding

Voltijd- of deeltijdvariant van gevolgde opleiding

Begindatum gevolgde opleiding

Einddatum gevolgde opleiding

Diploma of certicificaat behaald van gevolgde opleiding

Opnieuw kiezen van gevolgde opleiding

Hoogste vooropleiding

Vooropleiding voor hoogste vooropleiding

Vervolgopleiding

Voltijd- of deeltijdvariant van vervolgopleiding

Vervolgopleiding diploma/gestopt

Plaats van vervolgopleiding

Aansluiting vervolgopleiding op gevolgde opleiding

Cursus/bedrijfsopleiding

Cursus/bedrijfsopleiding totale duur

Cursus/bedrijfsopleiding aantal uren per week

$\mathrm{HBO} / \mathrm{WO}$

niet IVBO wel MBO/HBO/WO

$\mathrm{MBO}$ (beperkt)/HBO/WO

$\mathrm{MBO} / \mathrm{HBO} / \mathrm{WO}$

$\mathrm{HBO} / \mathrm{WO}$

$\mathrm{HBO} / \mathrm{WO}$

AVO/MBO

niet WO

niet voor AVO

$\mathrm{MBO} / \mathrm{HBO} / \mathrm{WO}$

$\mathrm{MBO} / \mathrm{HBO} / \mathrm{WO}$

$\mathrm{MBO} / \mathrm{HBO} / \mathrm{WO}$

bij kunst zowel betaalde als onbetaalde werkkringen

$\mathrm{MBO} / \mathrm{HBO} / \mathrm{WO}$

niet IVBO/(I)VBO groen en VAVO

niet $\mathrm{AVO}$ wel $\mathrm{MBO} / \mathrm{HBO}$

HAO en WO LUW

niet bij AVO

HAO en WO LUW

Huidige functie vereiste opleidingsrichting volgens schoolverlater

Huidige functie leidinggeven

Huidige functie arbeidsuren per week

Huidige functie bruto maandinkomen 
Overzicht kernvragen Schoolverlatersinformatiesysteem

Huidige functie aansluiting met gevolgde opleiding

Nevenfuncties

Nevenfuncties aantal uren per week

Opleiding-huidige functie: belang van kennis en technieken

Opleiding-huidige functie: belang van vaardigheden

Opleiding-huidige functie: belang van houdingsaspecten

Opleiding-huidige functie: aandacht voor kennis en technieken

Opleiding-huidige functie: aandacht voor vaardigheden

Opleiding-huidige functie: aandacht voor houdingsaspecten
$\mathrm{MBO}$ (beperkt)/HBO/WO

$\mathrm{MBO} / \mathrm{HBO} / \mathrm{WO}$

$\mathrm{MBO} / \mathrm{HBO} / \mathrm{WO}$

$\mathrm{MBO}$ (beperkt)/HBO/WO

$\mathrm{MBO}$ (beperkt)/HBO/WO

MBO (beperkt)/HBO/WO

$\mathrm{MBO}$ (beperkt)/HBO/WO

$\mathrm{MBO}$ (beperkt)/HBO/WO

MBO (beperkt)/HBO/WO 
